\title{
Association of Bisphenol A Exposure with LINE-1 Hydroxymethylation in Human Semen
}

\author{
Youping Tian ${ }^{1,2,+}$, Xiaoyu Zhou ${ }^{1,+}$, Maohua Miao ${ }^{1}$, De-kun Li ${ }^{3}$, Ziliang Wang ${ }^{1}$, Runsheng Li ${ }^{1, *}$, \\ Hong Liang ${ }^{1, *}$ and Wei Yuan ${ }^{1}$ \\ 1 Key Laboratory of Reproduction Regulation of NPFPC, SIPPR, IRD, Fudan University, Shanghai 200237, \\ China; 16211150003@fudan.edu.cn (Y.T.); zouxy2001@163.com (X.Z.); miaomaohua@163.com (M.M.); \\ wangziliang1986@126.com (Z.W.); yuanwei11@yahoo.com (W.Y.) \\ 2 School of Public Health, Fudan University, Shanghai 200032, China \\ 3 Division of Research, Kaiser Foundation Research Institute, Kaiser Permanente Northern California, \\ Oakland, CA 94612, USA; de-kun.li@kp.org \\ * Correspondence: runshengli2007@163.com (R.L.); lucylhcn@163.com (H.L.) \\ + These two authors contributed equally.
}

Received: 22 July 2018; Accepted: 16 August 2018; Published: 17 August 2018

\begin{abstract}
Bisphenol A (BPA), an exogenous endocrine-disrupting chemical, has been shown to alter DNA methylation. However, little information is available about the effect of BPA exposure on DNA hydroxymethylation in humans. The objective of the present study was to examine whether BPA exposure was associated with DNA hydroxymethylation in human semen samples. We measured urine BPA levels and LINE-1 hydroxymethylation in 158 male factory workers selected from an occupational cohort study conducted in China between 2004 and 2008. Among them, there were 72 male workers with occupational BPA exposure (BPA-exposed group) and 86 male workers without occupational BPA exposure (unexposed group). Multivariate linear regression models were used to examine the association of exposure to BPA with LINE-1 hydroxymethylation. LINE-1 was more highly hydroxymethylated in the BPA-exposed group than in the unexposed group (median $12.97 \%$ vs. $9.68 \%$, respectively; $p<0.05$ ), after adjusting for the potential confounders. The medians of 5-hydroxymethylcytosine $(5 \mathrm{hmC})$ generally increased with increasing urine BPA levels: $8.79 \%, 12.16 \%, 11.53 \%$, and $13.45 \%$, for undetected BPA and corresponding tertiles for the detected BPA, respectively. After analysis using data at individual level, our findings indicated that BPA exposure was associated with alterations of sperm LINE-1 hydroxymethylation, which might have implications for understanding the mechanisms underlying BPA-induced adverse effects on male reproductive function.
\end{abstract}

Keywords: Bisphenol A; sperm; DNA hydroxymethylation; LINE-1; 5hmC

\section{Introduction}

Bisphenol A (BPA), an exogenous endocrine-disrupting chemical, is extensively used in the production of polycarbonate plastic and epoxy resins [1] and is ubiquitously present in the environment, owing to the wide use of consumer products in daily life. In the United States, the Centers for Disease Control and Prevention (CDC) detected BPA in 95\% of urine samples in the general population using isotope dilution gas chromatography-mass spectrometry (GC-MS) [2]. In vitro studies have shown that BPA can interact with estrogen receptors $\alpha$ and $\beta$, leading to estrogenic effects [3], and act as an androgen receptor antagonist with strong anti-androgenic effects [4]. The endocrine-disrupting effects of BPA on male reproductive health have raised concerns over the past decades and a number of animal studies have shown that low environmental levels of BPA exposure can cause adverse effects on 
male reproduction [5,6]. In humans, several studies have demonstrated associations between BPA and semen quality parameters or reproductive hormones [7-9]. Our previous studies also found inverse associations between occupational BPA exposure and semen quality or male sexual function $[10,11]$. However, the molecular mechanism of BPA toxicity on human reproduction remains unclear.

Epigenetic features are highly sensitive to environmental exposures, and therefore can function as important biomarkers for the effects of environmental exposures [12,13]. The best-characterized epigenetic mark in sperm is DNA 5-methylcytosine $(5 \mathrm{mC})$ modification within CpG dinucleotides, which has been shown to be altered following BPA exposure [14,15]. A growing body of evidence suggests that BPA-induced alterations in DNA methylation might be an important intermediate in the pathway of BPA exposure and the impairment of male reproductive functions $[15,16]$. DNA methylation is involved in regulating promoter activity and is very dynamic since $5 \mathrm{mc}$ could be converted to 5 -hydroxymethylcytosine $(5 \mathrm{hmC})$, through consecutive oxidation reactions catalyzed by ten-eleven-translocation (TET) protein family members [17-19]. Given that $5 \mathrm{hmC}$ is mainly present at actively transcribed genes [20,21], and that it can bind chromatin regulator proteins, such as MeCP2 [22] and MBD3 [23], some researchers propose that $5 \mathrm{hmC}$ is a predominantly stable DNA modification distinct from $5 \mathrm{mC}$ and, therefore, is likely to have a different regulatory function rather than existing merely as a transient species [24]. The enrichment of $5 \mathrm{hmC}$ is potentially crucial for regulation of gene expression during spermatogenesis [25]. While two recent animal studies suggested that exposure to BPA inhibited global DNA hydroxymethylation or TETs-mediated DNA demethylation [26,27], little information is available about the effect of BPA exposure on global $5 \mathrm{hmC}$ in humans.

Long interspersed element-1 (LINE-1), comprising of approximately $17 \%$ of human genomic DNA [28], is the most abundant and the only active autonomous non-LTR retrotransposon in the human genome. Genomic studies have revealed that $5 \mathrm{hmC}$ is enriched in intergenic regions, such as LINE-1, satellites, and gene bodies of synaptic plasticity-related loci [29,30]. Gan et al. found that $5 \mathrm{hmC}$ is mainly located in long interspersed element sequences (LINEs) in pachytene spermatocytes (pacSC, one type of spermatogenic cells) [25]. Moreover, our recent genome-wide alteration study (GWAS) in DNA hydroxymethylation found that BPA could raise $5 \mathrm{hmC}$ rate in four sperm genes (AChE, ATP2A1, PPP2R3C, and LINE-1), using the pooled sperm samples [31]. In the present study, we examined the association between exposure to BPA and LINE-1 hydroxymethylation in individual semen samples (un-pooled analysis).

\section{Materials and Methods}

\subsection{Study Population and Data Collection}

In the present study, we included 158 male factory workers. The workers were selected from an occupational cohort study examining the health effects of occupational BPA exposure in several regions of China between 2004 and 2008, as previously described [10,11,14]. In brief, male workers (BPA-exposed group) were recruited from manufacturers of epoxy resin, who used BPA as one of their raw materials. We confirmed that they were exposed to BPA in the workplace via both spot and personal air sampling measurements. Unexposed workers were identified and recruited from factories which had no known BPA exposure and were not exposed to known reproductive toxicants in the workplace in the same region during the same time period. The control factories (e.g., construction material manufacturers, water supply factories, machinery factories and garment factories) were from the same jurisdiction of the health department overseeing the occupational health of the participating BPA-exposed factory. This study was performed by three academic and research institutions and was approved by the research ethics committees of all of them (ethical permit number: PJ2015-16). All participants gave written informed consent before participation in the study.

Among 514 recruited male workers, we selected two regions (Yueyang and Wuxi, $N=395$ ) for LINE-1 hydroxymethylation assay because of limited funding. Those who (1) were aged between 20 to 45 years and (2) have semen specimens available for the assay of hydroxymethylation and urine sample 
for assay of BPA were recruited to the present study. A total of 158 male workers were finally included in the present analysis, including 72 in BPA-exposed group and 86 in unexposed group. Through an in-person interview, all participants were asked to fill out a detailed questionnaire, including information on demographic characteristics, lifestyle factors (i.e., smoking and alcohol consumption) and history of diseases (i.e., acute or chronic disease of liver, kidney or other organs, diagnosed by a physician). In addition, they were asked to provide urine and semen specimens.

\subsection{BPA Measurement}

A detailed description of BPA measurement can be found elsewhere [10,11,14]. Briefly, two urine samples, pre-shift and post-shift, were collected from each male worker in the BPA-exposed group (varied between 7AM to 12PM depending on the schedule of shifts), and mean BPA concentrations of pre- and post-shift urine BPA of each worker were calculated and used to represent the actual BPA exposure levels for the statistical analyses. Only one spot urine sample was collected from workers in the BPA-unexposed group (varied between 8AM to 4PM) because their work shift should not have effects on their urine BPA levels. The total urinary concentrations of BPA (free plus conjugated species) were measured using high-performance liquid chromatography (HPLC), as described in a previous study [32]. We mixed urine samples with phosphorous acid buffer and $\beta$-glucuronidase (Sigma Chemical Co, St. Louis, MO, USA) for hydrolyzation, and then were extracted twice with ether (HPLC grade; Dikma, Lake Forest, CA, USA). The supernatants were evaporated with nitrogen gas and the residue was dissolved in $60 \%$ acetonitrile and analyzed by HPLC with fluorescence detection. The limit of detection (LOD) for BPA concentrations was $0.31 \mathrm{mg} / \mathrm{L}$, which was calculated with the method recommended by EPA [32], and was comparable to LODs reported in previous studies [1]. To account for urinary dilution, urinary BPA concentrations were divided by urinary creatinine concentrations and reported in micrograms per gram creatinine.

\subsection{Semen Collection}

The collection and examination of all semen specimens strictly followed the standards set by the World Health Organization [33]. Participants were asked to abstain from sexual activity for at least 2 days, but not exceeding 7 days, before the specimen collection. In a private room with a temperature of $20-28{ }^{\circ} \mathrm{C}$ a clean and wide-mouthed container was utilized to collect semen specimens through masturbation and ejaculation. We performed macroscopic (e.g., liquefaction, appearance, viscosity, volume and $\mathrm{pH}$ ) and microscopic analyses (e.g., concentration, motility, vitality and morphology) according to the WHO manual [33]. All semen analyses were conducted by the same technician to ensure consistency.

\subsection{DNA Extraction and Hydroxymethylation Measurement of LINE-1}

The sperm DNA was prepared as described in our previous study [14]. Briefly, the sperm DNA was extracted by treating sperm pellets with guanidine hydrochloride and sodium citrate, followed by precipitation with ethanol. Then sperm DNA was isolated by a standard phenol/chloroform extraction method and qualified by electrophoresis on an agarose gel and visualized with ethidium bromide.

DNA glucosylation and digestion was performed using the EpiMark 5-hmC and 5-mC Analysis Kit (NEB) which can be used to analyze and quantitate 5-mC and 5-hmC within a specific locus. Analyses were conducted according to the manufacturer's protocols. Briefly, DNA was first mixed with UDP-glucose, then split into two parts which were incubated with or without T4 beta-glucosyltransferase(T4- $\beta$ GT), respectively, for $16 \mathrm{~h}$ at $37^{\circ} \mathrm{C}$. This glucosylation was followed by restriction endonuclease digestion. Both reaction mixtures were then run in triplicate which were mock digested, digested with MspI, or digested with HpaII for at least $4 \mathrm{~h}$. Samples were treated with proteinase $\mathrm{K}$ and incubated at $40^{\circ} \mathrm{C}$ for $30 \mathrm{~min}$. Proteinase $\mathrm{K}$ was then inactivated by incubating at $95^{\circ} \mathrm{C}$ for $10 \mathrm{~min}$. The fraction of glycosylated DNA and therefore protected MspI sites as well as the fraction of $5 \mathrm{mC}$ - and $5 \mathrm{hmC}$-sensitive sites (determined using HpaII restriction) at specific gene loci 
in LINE-1 were quantified by qPCR using primers [34]. Schematic representation of location of the CCGG loci in the 5UTR of LINE-1 was presented in Figure 1. The rate of hydroxymethylation was calculated using the formulae in the kit according to the manufacturer's protocols.

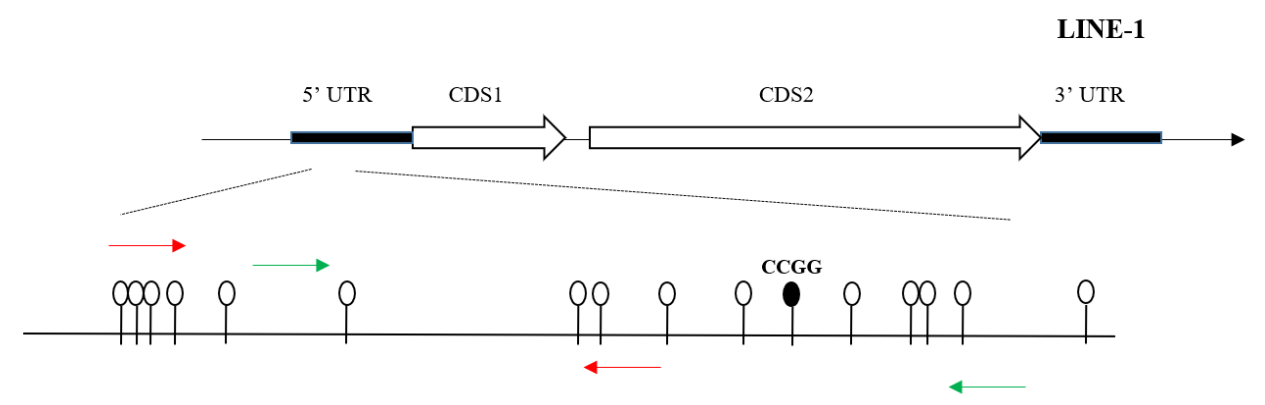

Figure 1. Schematic representation of location of the CCGG loci in the 5UTR of LINE-1.

The red line indicates the region where enrichment of BPA-associated $5 \mathrm{hmc}$ was detected through high-throughput sequencing, and it is 200-bp long in LINE-1. The green line represents the location of qPCR product.

\subsection{Statistical Analyses}

Descriptive statistics on subject characteristics were tabulated by BPA occupational exposure status. All participants were further divided into four groups by urinary BPA level: BPA undetectable (lower than LOD), and lowest tertile, middle tertile and highest tertile among those with detectable BPA. We calculated means (SD) and percentiles for the distributions of $5 \mathrm{hmC}$ by occupational BPA exposure (yes or no) and urinary level of BPA as mentioned above. Multivariate linear regression models were used to examine the association between BPA exposure as categorized variables with hydroxymethylation of LINE-1. The following variables were adjusted as potential confounders: age, smoking, alcohol consumption and history of disease, which had been reported to be associated with DNA hydroxymethylation [35-37]. In addition, to examine a potential modifying effect on the association between BPA exposure and DNA hydroxymethylation of LINE-1, stratified analyses were conducted by age, smoking status, alcohol consumption and history of disease due to their known effects on $5 \mathrm{hmC}$.

We ran similar linear regressions with BPA concentration (log transformed) as a continuous variable to examine its linear relationship with hydroxymethylation of LINE-1. The concentration of the BPA below the LOD was replaced with $\mathrm{LOD} / \sqrt{ } 2$ as a widely accepted method. All statistical analyses were performed using SAS version 9.3 (SAS Institute Inc., Cary, NC, USA).

\section{Results}

Characteristics of exposed and unexposed male workers are presented in Table 1 . The occupational BPA-exposed group had a higher proportion of males aged 30-35 years, although with a similar average age ( $34.1 \pm 8.3$ vs. $34.4 \pm 9.6)$ as those in the unexposed group. The BPA-exposed group was less educated and less likely to be tobacco smokers or alcohol drinkers. Urine BPA concentrations are described in Table 2. The geometric mean (GM) of adjusted creatinine urine BPA concentration was significantly higher in the BPA-exposed group $(158.41 \mu \mathrm{g} / \mathrm{g} \mathrm{Cr}$ in the exposed group vs. $0.84 \mu \mathrm{g} / \mathrm{g} \mathrm{Cr}$ in the unexposed group). The GMs of urine BPA concentration were $3.77 \mu \mathrm{g} / \mathrm{g} \mathrm{Cr}, 33.94 \mu \mathrm{g} / \mathrm{g} \mathrm{Cr}$, and $1698.88 \mu \mathrm{g} / \mathrm{g} \mathrm{Cr}$ for the lowest tertile, middle tertile, and highest tertile, respectively, for the group with detectable BPA. 
Table 1. Characteristics of workers in the BPA-exposed and unexposed groups.

\begin{tabular}{|c|c|c|c|}
\hline Characteristics & Exposed $(n=72)$ & Unexposed $(n=86)$ & $p$ \\
\hline \multicolumn{4}{|l|}{ Age (years) } \\
\hline$<29$ & $23(31.94)$ & $32(37.21)$ & \multirow{3}{*}{0.48} \\
\hline $30-35$ & $21(29.17)$ & $18(21.18)$ & \\
\hline$>36$ & $28(38.89)$ & $36(41.86)$ & \\
\hline \multicolumn{4}{|l|}{ Education } \\
\hline$\leq$ Middle school & $21(29.17)$ & $20(23.26)$ & \multirow{3}{*}{0.57} \\
\hline High school & $39(54.17)$ & $47(54.65)$ & \\
\hline$\geq$ College & $12(16.67)$ & $19(22.09)$ & \\
\hline \multicolumn{4}{|l|}{ Smoking } \\
\hline Yes & $47(65.28)$ & $60(69.77)$ & \multirow{2}{*}{0.55} \\
\hline No & $25(34.72)$ & $26(30.23)$ & \\
\hline \multicolumn{4}{|c|}{ Alcohol consumption } \\
\hline Yes & $16(22.22)$ & $22(25.58)$ & \multirow{2}{*}{0.62} \\
\hline No & $56(77.78)$ & $64(74.42)$ & \\
\hline \multicolumn{4}{|l|}{ History of disease } \\
\hline Yes & $13(18.06)$ & $16(18.60)$ & \multirow{2}{*}{0.93} \\
\hline No & $59(81.94)$ & $70(81.40)$ & \\
\hline
\end{tabular}

Table 2. Urine BPA levels ( $\mu \mathrm{g} / \mathrm{g}$ creatinine) between groups.

\begin{tabular}{cccc}
\hline Groups & $N$ & GM (std) & Median (Q1, Q3) \\
\hline By occupational exposure status & & & \\
BPA-exposed & 72 & $158.41(17.92)$ & $238.78(24.14,2043.22)$ \\
Unexposed & 86 & $0.84(6.53)$ & LOD (LOD, 6.07) \\
\hline By urine BPA level & & & \\
\hline BPA undetectable (below LOD) & 53 & LOD & LOD \\
Low tertile (0-13.28) & 35 & $3.77(3.07)$ & $4.78(1.55,8.19)$ \\
Middle tertile (13.28-274.82) & 35 & $33.94(2.13)$ & $30.88(22.67,53.72)$ \\
Top tertile (274.82-) & 35 & $1698.88(6.74)$ & $2158.44(679.92,9771.63)$ \\
\hline
\end{tabular}

The spermatic LINE-1 was more highly hydroxymethylated in the BPA-exposed group than in the unexposed group (median $12.97 \%$ vs. $9.68 \%$; $p<0.05$; Table 3), after adjusting for potential confounders. When dose-dependent effects were examined, the medians of $5 \mathrm{hmC}$ generally increased with increasing urine BPA level: $8.79 \%, 12.16 \%, 11.53 \%$, and 13.45\%, for undetected BPA and corresponding tertiles among detected BPA, respectively (Table 3). However, we did not observe a linear association between natural log transformed urine BPA levels and LINE-1 hydroxymethylation (data not shown).

Table 3. BPA exposure and the 5hmC rate of LINE-1.

\begin{tabular}{|c|c|c|c|c|c|c|c|c|c|}
\hline Groups & $N$ & Mean \% (std) & 5 th $\%$ & 25 th $\%$ & 50 th $\%$ & 75 th $\%$ & 95th $\%$ & $\beta$ & $p$ \\
\hline \multicolumn{10}{|c|}{ By occupational exposure status } \\
\hline Unexposed & 86 & $9.68(4.97)$ & 2.13 & 6.48 & 8.99 & 11.62 & 20.95 & Ref & - \\
\hline Exposed & 72 & $12.97(5.07)$ & 5.62 & 9.51 & 12.45 & 15.71 & 23.45 & 0.034 & $<0.0001$ \\
\hline \multicolumn{10}{|c|}{ By urine BPA level } \\
\hline BPA undetected & 53 & $8.79(4.22)$ & 1.91 & 6.32 & 8.36 & 10.24 & 16.09 & Ref & - \\
\hline Low tertile & 35 & $12.16(5.75)$ & 5.25 & 6.92 & 11.85 & 17.13 & 22.55 & 0.031 & 0.006 \\
\hline Middle tertile & 35 & $11.53(4.58)$ & 5.99 & 8.54 & 10.26 & 15.22 & 21.51 & 0.023 & 0.047 \\
\hline Top tertile & 35 & $13.45(5.58)$ & 4.71 & 10.23 & 12.71 & 18.46 & 24.15 & 0.048 & $<0.0001$ \\
\hline
\end{tabular}

Adjusted for: age, history of disease, smoking and alcohol consumption. 
We performed analyses stratified by worker's age, smoking, alcohol consumption and history of disease. The difference in spermatic LINE-1 hydroxymethylation between the BPA-exposed group and unexposed group remained essentially unchanged across the subcategories although some estimations were attenuated slightly and became non-significant due to small sample sizes (Table 4).

Table 4. Linear regression of occupational BPA exposure and hydroxymethylation in LINE-1 upon stratification.

\begin{tabular}{|c|c|c|c|c|c|}
\hline \multirow{2}{*}{ Stratified Analysis } & \multirow{2}{*}{$N$} & \multicolumn{2}{|c|}{ Crude } & \multicolumn{2}{|c|}{ Adjusted } \\
\hline & & $\beta$ & $p$ & $\beta$ & $p$ \\
\hline \multicolumn{6}{|c|}{ Smoking } \\
\hline $\mathrm{NO}$ & 51 & 0.042 & 0.002 & 0.047 & 0.001 \\
\hline YES & 107 & 0.029 & 0.005 & 0.028 & 0.007 \\
\hline \multicolumn{6}{|c|}{ Alcohol consumption } \\
\hline $\mathrm{NO}$ & 120 & 0.034 & $<0.001$ & 0.035 & $<0.001$ \\
\hline YES & 38 & 0.031 & 0.073 & 0.027 & 0.148 \\
\hline \multicolumn{6}{|c|}{ Age group (years) } \\
\hline$<30$ & 55 & 0.030 & 0.047 & 0.031 & 0.046 \\
\hline $30-36$ & 39 & 0.017 & 0.334 & 0.013 & 0.473 \\
\hline$\geq 36$ & 64 & 0.040 & $<0.001$ & 0.045 & $<0.001$ \\
\hline \multicolumn{6}{|c|}{ Disease } \\
\hline $\mathrm{NO}$ & 129 & 0.035 & $<0.001$ & 0.036 & $<0.001$ \\
\hline YES & 29 & 0.023 & 0.167 & 0.025 & 0.167 \\
\hline
\end{tabular}

Smoking was not adjusted in the stratified analysis by smoking, drinking was not adjusted in the stratified analysis by alcohol consumption, age was not adjusted in the stratified analysis by age, and disease was not adjusted in the stratified analysis by disease.

\section{Discussion}

We observed that BPA exposure (based on both occupational BPA exposure status and urinary BPA concentrations divided into four groups) was associated with increased LINE-1 hydroxymethylation in sperm using individual specimens. Similar associations were also found in stratified analyses.

To our knowledge, this is the first epidemiological study on DNA hydroxymethylation in individual human sperm in relation to BPA exposure. Only two previous animal studies have examined the relationship between BPA exposure and global DNA hydroxymethylation, where maternal exposure to BPA inhibited global DNA hydroxymethylation in adult rat testis and BPA exposure led to a decrease of testicular TETs and 5hmC levels in Gobiocypris rarus testes [26]. 5hmC density and function appears to vary with cell type, differentiation stage and gene specific function [38]. Therefore, different cell types and genes analyzed in these studies and the disparity of species-specific transposon complement [39] may be the potential explanation for the inconsistent results. There are several potential mechanisms whereby BPA exposure could increase $5 \mathrm{hmC}$. First, BPA exposure increases the generation of reactive oxygen species (ROS) [40,41], which can activate the TET protein family members that induce oxidation of $5 \mathrm{mC}$ into $5 \mathrm{hmC}$ [42]. Consistent with this model, previous studies have demonstrated that ROS-inducing chemicals, like hydroquinone and particulate matter, increase genome-wide and gene-specific $5 \mathrm{hmC}$ formation [43-45]. Another possible mechanism is through metabolic alterations that could change the rate of generation of $5 \mathrm{hmC}$. BPA could influence the tricarboxylic acid cycle [46], thereby increasing the levels of $\alpha$-ketoglutarate $(\alpha-K G)$, a known substrate for TET-catalyzed oxidation of $5 \mathrm{mC}$ to $5 \mathrm{hmC}$ [47]. In addition, one recent study has suggested that BPA might prevent initiation of the base excision repair (BER) pathway [48], which is required for demethylation of $5 \mathrm{hmC}$ [49]. 
In contrast to our previously published study [14], here we observed a more profound difference of LINE-1 hydroxymethylation than methylation (alterations of $34 \%$ for $5 \mathrm{hmC}$, and $5 \%$ for $5 \mathrm{mC}$ ) between the BPA-exposed group and unexposed group. While $5 \mathrm{mc}$ is associated with repression of gene expression, $5 \mathrm{hmC}$ is specifically present at actively transcribed genes and is mainly involved in activating gene expression [50]. Given that the $5 \mathrm{hmC}$ profile shows a better correlation with gene expression compared to $5 \mathrm{mC}$ [51], $5 \mathrm{hmC}$ may function as a more sensitive biomarker than $5 \mathrm{mC}$ in response to BPA exposure.

In addition, $5 \mathrm{hmC}$ content is positively correlated with the expression of retrotransposons (including LINEs, SINEs, LTRs, and satellites) during spermatogenesis [25]. Considering that the activation of LINE-1 retrotransposons is linked with male infertility [52], the increase of $5 \mathrm{hmC}$ level in sperm LINE-1 might have implications for understanding the mechanisms underlying BPA-induced impairment of male reproductive function. Moreover, exploring the associations between LINE-1 hydroxymethylation and BPA exposure by analyzing semen specimens rather than other tissues is more straight-forward and accurate for understanding the potential epigenetic effects of BPA-induced male infertility.

There are several limitations in our study. First, our sample size was relatively small which may have resulted in false negative findings or chance findings that limit the generalizability. Second, single-spot urine sample for assessing BPA exposure in the unexposed group may have resulted in a measurement error due to the relatively short half-life of BPA. However, the measurement error was likely non-differential, which would bias the association toward null, as previously reported [11,14]. Additionally, we did not perform "Spermatozoa purification" to separate spermatozoa from cellular contaminants since a similar protocol was used in several studies examining sperm DNA methylation in humans $[53,54]$, which may have potential contamination by round cells. We did not collect information on BPA exposure relevant lifestyle factors, which may cause non-differential misclassification, and thus bias the association toward null. Finally, similar to other sperm studies, a proportion of participants declined to provide biological samples (urine and semen) which may have led to a selection bias.

\section{Conclusions}

In the present study, our data indicate that occupational exposure to BPA is positively associated with LINE-1 hydroxymethylation in human semen samples. Thus, our findings provide supportive evidence that $5 \mathrm{hmC}$ may function as a new epigenetic modification for epidemiological studies on the impact of BPA, or other environmental toxicants on male semen quality.

Author Contributions: Data curation, X.Z. and M.M.; Methodology, M.M., R.L., H.L. and W.Y.; Project administration, M.M. and H.L.; Writing—original draft, Y.T.; Writing-review \& editing, Y.T., X.Z., M.M., D.L., Z.W., R.L., H.L. and W.Y.

Acknowledgments: This work was supported by grants from the National Natural Science Foundation of China (81501318 and 81571495); the National key research and development program [2016YFC1000505]; the National Basic Research Program of China [2014CB943104]; Science and Technology Commission of Shanghai Municipality [15431902800 and 15140903100], Shanghai Municipal Commission of Health and Family Planning [15GWZK0201] and Innovation-oriented Science and Technology Grant from NPFPC Key Laboratory of Reproduction Regulation (CX2017-06 and CX2017-07).

Conflicts of Interest: The authors declare no conflict of interest. The funding sponsor had no role in the design of the study; in the collection analyses, or interpretation of data; in the writing of the manuscript, and in the decision to publish the results.

\section{References}

1. Calafat, A.M.; Ye, X.; Wong, L.Y.; Reidy, J.A.; Needham, L.L. Exposure of the U.S. Population to Bisphenol A and 4-Tertiary-Octylphenol: 2003-2004. Environ. Health Perspect. 2008, 116, 39-44. [CrossRef] [PubMed]

2. Calafat, A.M.; Kuklenyik, Z.; Reidy, J.A.; Caudill, S.P.; Ekong, J.; Needham, L.L. Urinary Concentrations of Bisphenol A and 4-Nonylphenol in a Human Reference Population. Environ. Health Perspect. 2005, 113, 391-395. [CrossRef] [PubMed] 
3. Gould, J.C.; Leonard, L.S.; Maness, S.C.; Wagner, B.L.; Conner, K.; Zacharewski, T.; Safe, S.; Mcdonnell, D.P.; Gaido, K.W. Bisphenol A Interacts with the Estrogen Receptor $\alpha$ in a Distinct Manner from Estradiol. Mol. Cell. Endocrinol. 1998, 142, 203-214. [CrossRef]

4. Bonefeld-Jørgensen, E.C.; Long, M.; Hofmeister, M.V.; Vinggaard, A.M. Endocrine-Disrupting Potential of Bisphenol A, Bisphenol A Dimethacrylate, 4-n-Nonylphenol, and 4-n-Octylphenol in Vitro: New Data and a Brief Review. Environ. Health Perspect. 2007, 115, 69-76. [CrossRef] [PubMed]

5. Qiu, L.L.; Wang, X.; Zhang, X.H.; Zhang, Z.; Gu, J.; Liu, L.; Wang, Y.; Wang, X.; Wang, S.L. Decreased Androgen Receptor Expression May Contribute to Spermatogenesis Failure in Rats Exposed to Low Concentration of Bisphenol A. Toxicol. Lett. 2013, 219, 116-124. [CrossRef] [PubMed]

6. Tainaka, H.; Takahashi, H.; Umezawa, M.; Tanaka, H.; Nishimune, Y.; Oshio, S.; Takeda, K. Evaluation of the Testicular Toxicity of Prenatal Exposure to Bisphenol A Based on Microarray Analysis Combined with MeSH Annotation. J. Toxicol. Sci. 2012, 37, 539-548. [CrossRef] [PubMed]

7. Lassen, T.H.; Frederiksen, H.; Jensen, T.K.; Petersen, J.H.; Joensen, U.N.; Main, K.M.; Skakkebaek, N.E.; Juul, A.; Jørgensen, N.; Andersson, A.-M. Urinary Bisphenol A Levels in Young Men: Association with Reproductive Hormones and Semen Quality. Environ. Health Perspect. 2014, 122, 478-484. [CrossRef] [PubMed]

8. Goldstone, A.E.; Chen, Z.; Perry, M.J.; Kannan, K.; Louis, G.M.B. Urinary Bisphenol a and Semen Quality: The Life Study. Reprod. Toxicol. 2015, 51,7-13. [CrossRef] [PubMed]

9. Meeker, J.D.; Ehrlich, S.; Toth, T.L.; Wright, D.L.; Calafat, A.M.; Trisini, A.T.; Ye, X.; Hauser, R. Semen quality and sperm DNA damage in relation to urinary bisphenol A among men from an infertility clinic. Reprod. Toxicol. 2010, 30, 532-539. [CrossRef] [PubMed]

10. Li, D.-K.; Zhou, Z.; Miao, M.; He, Y.; Qing, D.; Wu, T.; Wang, J.; Weng, X.; Ferber, J.; Herrinton, L.J.; et al. Relationship Between Urine Bisphenol-A Level and Declining Male Sexual Function. J. Androl. 2010, 31, 500-506. [CrossRef] [PubMed]

11. Li, D.K.; Zhou, Z.; Miao, M.; He, Y.; Wang, J.; Ferber, J.; Herrinton, L.J.; Gao, E.; Yuan, W. Urine bisphenol-A (BPA) level in relation to semen quality. Fertil. Steril. 2011, 95, 625-630. [CrossRef] [PubMed]

12. Hou, L.; Zhang, X.; Wang, D.; Baccarelli, A. Environmental chemical exposures and human epigenetics. Int. J. Epidemiol. 2012, 41, 79-105. [CrossRef] [PubMed]

13. Fleisch, A.F.; Wright, R.O.; Baccarelli, A.A. Environmental epigenetics: A role in endocrine disease? J. Mol. Endocrinol. 2012, 49, 61-67. [CrossRef] [PubMed]

14. Miao, M.; Zhou, X.; Li, Y.; Zhang, O.; Zhou, Z.; Li, T.; Yuan, W.; Li, R.; Li, D.-K. LINE-1 Hypomethylation in Spermatozoa Is Associated with Bisphenol A Exposure. Andrology-US 2014, 2, 138-144. [CrossRef] [PubMed]

15. Manikkam, M.; Tracey, R.; Guerrero-Bosagna, C.; Skinner, M.K. Plastics derived endocrine disruptors (BPA, DEHP and DBP) induce epigenetic transgenerational inheritance of obesity, reproductive disease and sperm epimutations. PLoS ONE 2013, 8, e55387. [CrossRef] [PubMed]

16. Yin, L.; Dai, Y.; Jiang, X.; Liu, Y.; Chen, H.; Han, F.; Cao, J.; Liu, J. Role of DNA Methylation in Bisphenol A Exposed Mouse Spermatocyte. Environ Toxicol. Pharmacol. 2016, 48, 265-271. [CrossRef] [PubMed]

17. Kriaucionis, S.; Heintz, N. The nuclear DNA base 5-hydroxymethylcytosine is present in Purkinje neurons and the brain. Science 2009, 324, 929-930. [CrossRef] [PubMed]

18. Tahiliani, M.; Koh, K.P.; Shen, Y.; Pastor, W.A.; Bandukwala, H.; Brudno, Y.; Agarwal, S.; Iyer, L.M.; Liu, D.R.; Aravind, L.; et al. Conversion of 5-methylcytosine to 5-hydroxymethylcytosine in mammalian DNA by MLL partner TET1. Science 2009, 324, 930-935. [CrossRef] [PubMed]

19. Ito, S.; D' Alessio, A.C.; Taranova, O.V.; Hong, K.; Sowers, L.C.; Zhang, Y. Role of Tet proteins in 5mC to 5hmC conversion, ES cell self-renewal, and ICM specification. Nature 2010, 466, 1129. [CrossRef] [PubMed]

20. Yu, M.; Hon, G.C.; Szulwach, K.E.; Song, C.X.; Zhang, L.; Kim, A.; Li, X.; Dai, Q.; Shen, Y.; Park, B.; et al. Base-resolution analysis of 5-hydroxymethylcytosine in the mammalian genome. Cell 2012, 149, 1368-1380. [CrossRef] [PubMed]

21. Williams, K.; Christensen, J.; Pedersen, M.T.; Johansen, J.V.; Cloos, P.A.; Rappsilber, J.; Helin, K. TET1 and hydroxymethylcytosine in transcription and DNA methylation fidelity. Nature 2011, 473, 343-348. [CrossRef] [PubMed]

22. Mellen, M.; Ayata, P.; Dewell, S.; Kriaucionis, S.; Heintz, N. MeCP2 binds to 5hmC enriched within active genes and accessible chromatin in the nervous system. Cell 2012, 151, 1417-1430. [CrossRef] [PubMed] 
23. Yildirim, O.; Li, R.; Hung, J.H.; Chen, P.B.; Dong, X.; Ee, L.S.; Weng, Z.; Rando, O.J; Fazzio, T.G. Mbd3/NURD complex regulates expression of 5-hydroxymethylcytosine marked genes in embryonic stem cells. Cell 2011, 147, 1498-1510. [CrossRef] [PubMed]

24. Bachman, M.; Uribe-Lewis, S.; Yang, X.; Williams, M.; Murrell, A.; Balasubramanian, S. 5-Hydroxymethylcytosine is a predominantly stable DNA modification. Nat. Chem. 2014, 6, 1049-1055. [CrossRef] [PubMed]

25. Gan, H.; Wen, L.; Liao, S.; Lin, X.; Ma, T.; Liu, J.; Song, C.-X.; Wang, M.; He, C.; Han, C.; et al. Dynamics of 5-Hydroxymethylcytosine during Mouse Spermatogenesis. Nat. Commun. 2013, 4, 1995. [CrossRef] [PubMed]

26. Abdel-Maksoud, F.M.; Leasor, K.R.; Butzen, K.; Braden, T.D.; Akingbemi, B.T. Prenatal Exposures of Male Rats to the Environmental Chemicals Bisphenol A and Di(2-Ethylhexyl) Phthalate Impact the Sexual Differentiation Process. Endocrinology 2015, 156, 4672-4683. [CrossRef] [PubMed]

27. Yuan, C.; Zhang, Y.; Liu, Y.; Wang, S.; Wang, Z. DNA demethylation mediated by down-regulated TETs in the testes of rare minnow Gobiocypris rarus under bisphenol A exposure. Chemosphere 2017, 171, 355-361. [CrossRef] [PubMed]

28. Lander, E.S.; Linton, L.M.; Birren, B.; Nusbaum, C.; Zody, M.C.; Baldwin, J.; Devon, K.; Dewar, K.; Doyle, M.; FitzHugh, W.; et al. Initial sequencing and analysis of the human genome. Nature 2001, 409, 860-921. [PubMed]

29. Khare, T.; Pai, S.; Koncevicius, K.; Pal, M.; Kriukiene, E.; Liutkeviciute, Z.; Irimia, M.; Jia, P.; Ptak, C.; Xia, M.; et al. 5-HmC in the Brain Is Abundant in Synaptic Genes and Shows Differences at the Exon-Intron Boundary. Nat. Struct. Mol. Biol. 2012, 19, 1037-1043. [CrossRef] [PubMed]

30. Booth, M.J.; Branco, M.R.; Ficz, G.; Oxley, D.; Krueger, F.; Reik, W.; Balasubramanian, S. Quantitative sequencing of 5-methylcytosine and 5-hydroxymethylcytosine at single-base resolution. Science 2012, 336, 934-937. [CrossRef] [PubMed]

31. Zheng, H.; Zhou, X.; Li, D.-K.; Yang, F.; Pan, H.; Li, T.; Miao, M.; Li, R.; Yuan, W. Genome-Wide Alteration in DNA Hydroxymethylation in the Sperm from Bisphenol A-Exposed Men. PLoS ONE 2017, 12, e178535. [CrossRef] [PubMed]

32. He, Y.; Miao, M.; Herrinton, L.J.; Wu, C.; Yuan, W.; Zhou, Z.; Li, D.-K. Bisphenol A Levels in Blood and Urine in a Chinese Population and the Personal Factors Affecting the Levels. Environ. Res. 2009, 109, 629-633. [CrossRef] [PubMed]

33. World Health Organization. WHO Laboratory Manual for the Examination of Human Semen and Sperm-Cervical Mucus Interaction, 4th ed.; Cambridge University Press: Cambridge, UK, 1999.

34. Hur, K.; Cejas, P.; Feliu, J.; Moreno-Rubio, J.; Burgos, E.; Boland, C.R.; Goel, A. Hypomethylation of Long Interspersed Nuclear Element-1 (LINE-1) Leads to Activation of Proto-Oncogenes in Human Colorectal Cancer Metastasis. Gut 2013, 63, 635-646. [CrossRef] [PubMed]

35. Tammen, S.A.; Dolnikowski, G.G.; Ausman, L.M.; Liu, Z.; Sauer, J.; Friso, S.; Choi, S.-W. Aging and Alcohol Interact to Alter Hepatic DNA Hydroxymethylation. Alcohol. Clin. Exp. Res. 2014, 38, 2178-2185. [CrossRef] [PubMed]

36. Tellez-Plaza, M.; Tang, W.-Y.; Shang, Y.; Umans, J.G.; Francesconi, K.A.; Goessler, W.; Ledesma, M.; Leon, M.; Laclaustra, M.; Pollak, J.; et al. Association of Global DNA Methylation and Global DNA Hydroxymethylation with Metals and Other Exposures in Human Blood DNA Samples. Environ. Health Perspect. 2014, 122, 229-239. [CrossRef] [PubMed]

37. Costa, L.A.; Da, S.I.; Mariz, B.A.; Da, S.M.; Freitas-Ribeiro, G.M.; de Oliveira, N.F. Influence of smoking on methylation and hydroxymethylation levels in global DNA and specific sites of KRT14, KRT19, MIR-9-3 and MIR-137 genes of oral mucosa. Arch. Oral Biol. 2016, 72, 56-65. [CrossRef] [PubMed]

38. James, S.J.; Shpyleva, S.; Melnyk, S.; Pavliv, O.; Pogribny, I.P. Elevated 5-hydroxymethylcytosine in the Engrailed-2 (EN-2) promoter is associated with increased gene expression and decreased MeCP2 binding in autism cerebellum. Transl. Psychiatry 2014, 4, e460. [CrossRef] [PubMed]

39. Huang, C.R.; Burns, K.H.; Boeke, J.D. Active transposition in genomes. Annu. Rev. Genet. 2012, 46, 651-675. [CrossRef] [PubMed]

40. Xin, F.; Jiang, L.; Liu, X.; Geng, C.; Wang, W.; Zhong, L.; Yang, G.; Chen, M. Bisphenol A Induces Oxidative Stress-Associated DNA Damage in INS-1 Cells. Mutat. Res. Genet. Toxicol. Environ. Mutagen. 2014, 769, 29-33. [CrossRef] [PubMed] 
41. Kazemi, S.; Mousavi, S.N.; Aghapour, F.; Rezaee, B.; Sadeghi, F.; Moghadamnia, A.A. Induction Effect of Bisphenol A on Gene Expression Involving Hepatic Oxidative Stress in Rat. Oxid. Med. Cell. Longev. 2016, 2016, 6298515. [CrossRef] [PubMed]

42. Chia, N.; Wang, L.; Lu, X.; Senut, M.C.; Brenner, C.; Ruden, D.M. Hypothesis: Environmental regulation of 5-hydroxymethylcytosine by oxidative stress. Epigenetics-US 2011, 6, 853-856. [CrossRef]

43. Niedzwiecki, M.M.; Liu, X.; Hall, M.N.; Thomas, T.; Slavkovich, V.; Ilievski, V.; Levy, D.; Alam, S.; Siddique, A.B.; Parvez, F.; et al. Sex-Specific Associations of Arsenic Exposure with Global DNA Methylation and Hydroxymethylation in Leukocytes: Results from Two Studies in Bangladesh. Cancer Epidemiol. Biomarkers Prev. 2015, 24, 1748-1757. [CrossRef] [PubMed]

44. Sanchez-Guerra, M.; Zheng, Y.; Osorio-Yanez, C.; Zhong, J.; Chervona, Y.; Wang, S.; Chang, D.; McCracken, J.P.; Díaz, A.; Bertazzi, P.A.; et al. Effects of particulate matter exposure on blood 5-hydroxymethylation: Results from the Beijing truck driver air pollution study. Epigenetics 2015, 10, 633-642. [CrossRef] [PubMed]

45. Coulter, J.B.; O'Driscoll, C.M.; Bressler, J.P. Hydroquinone increases 5-hydroxymethylcytosine formation through ten eleven translocation 1 (TET1) 5-methylcytosine dioxygenase. J. Biol. Chem. 2013, 288, 28792-28800. [CrossRef] [PubMed]

46. Rahman, M.S.; Kwon, W.S.; Lee, J.S.; Yoon, S.J.; Ryu, B.Y.; Pang, M.G. Bisphenol-A affects male fertility via fertility-related proteins in spermatozoa. Sci. Rep. 2015, 5, 9169. [CrossRef] [PubMed]

47. Yang, H.; Lin, H.; Xu, H.; Zhang, L.; Cheng, L.; Wen, B.; Shou, J.; Guan, K.; Xiong, Y.; Ye, D. TET-Catalyzed 5-Methylcytosine Hydroxylation Is Dynamically Regulated by Metabolites. Cell Res. 2014, 24, 1017-1020. [CrossRef] [PubMed]

48. Gassman, N.R.; Coskun, E.; Stefanick, D.F.; Horton, J.K.; Jaruga, P.; Dizdaroglu, M.; Wilson, S.H. Bisphenol A Promotes Cell Survival Following Oxidative DNA Damage in Mouse Fibroblasts. PLoS ONE 2015, 10, e118819. [CrossRef] [PubMed]

49. Guo, J.U.; Su, Y.; Zhong, C.; Ming, G.L.; Song, H. Hydroxylation of 5-methylcytosine by TET1 promotes active DNA demethylation in the adult brain. Cell 2011, 145, 423-434. [CrossRef] [PubMed]

50. Branco, M.R.; Ficz, G.; Reik, W. Uncovering the role of 5-hydroxymethylcytosine in the epigenome. Nat. Rev. Genet. 2011, 13, 7-13. [CrossRef] [PubMed]

51. Colquitt, B.M.; Allen, W.E.; Barnea, G.; Lomvardas, S. Alteration of genic 5-hydroxymethylcytosine patterning in olfactory neurons correlates with changes in gene expression and cell identity. Proc. Natl. Acad. Sci. USA 2013, 110, 14682-14687. [CrossRef] [PubMed]

52. Frost, R.J.; Hamra, F.K.; Richardson, J.A.; Qi, X.; Bassel-Duby, R.; Olson, E.N. MOV10L1 is necessary for protection of spermatocytes against retrotransposons by Piwi-interacting RNAs. Proc. Natl. Acad. Sci. USA 2010, 107, 11847-11852. [CrossRef] [PubMed]

53. Tunc, O.; Tremellen, K. Oxidative DNA damage impairs global sperm DNA methylation in infertile men. J. Assist. Reprod. Genet. 2009, 26, 537-544. [CrossRef] [PubMed]

54. Nanassy, L.; Carrell, D.T. Analysis of the methylation pattern of six gene promoters in sperm of men with abnormal protamination. Asian J. Androl. 2011, 13, 342-346. [CrossRef] [PubMed]

(C) 2018 by the authors. Licensee MDPI, Basel, Switzerland. This article is an open access article distributed under the terms and conditions of the Creative Commons Attribution (CC BY) license (http:/ / creativecommons.org/licenses/by/4.0/). 